\title{
Ubah Perilaku dengan Pendekatan Teori Pembelajaran Behaviouristik
}

\author{
Ferdiyanto, Frengki Salim, Lisabet Ajang, Arni Lestari
}

\begin{abstract}
ABSTRAK
Teori belajar behavioristik merupakan teori belajar yang lebih mengutamakan pada perubahan tingkah laku siswa sebagai akibat adanya stimulus dan respon. Dengan kata lain, belajar merupakan bentuk perubahan yang dialami siswa dalam hal kemampuannya yang bertujuan merubah tingkah laku dengan cara interaksi antara stimulus dan respon. Menurut Watson, tingkah laku siswa merupakan hasil dari pembawaan genetis dan pengaruh lingkungan. Sedangkan menurut Pavlov merujuk pada sejumlah prosedur pelatihan antara satu stimulus dan rangsangan muncul untuk menggantikan stimulus lain dalam mengembangkan respon, terakhir menurut Skinner hubungan antara stimulus dan respon terjadi karena melalui interaksi dengan lingkungan yang kemudian menimbulkan perubahan tingkah laku. Dengan demikian, teori belajar behaviouristic lebih memfokuskan untuk mengembangkan tingkah laku siswa ke arah yang lebih baik. ${ }^{1}$

Berbagai pihak atau kalangan selalu menyoroti mutu Pendidikan termasuk mutu Pendidikan di Indonesia. Mutu Pendidikan di Indonesia sangat dipengaruhi oleh mutu pembelajaran yang dilakukan guru di kelas. Pendidikan yang bermutu adalah Pendidikan yang mampu mengubah piskologis peserta didik. Aliran piskologi belajar yang sangat besar dipengaruhi arah pengembangan teori dan praktik Pendidikan, pembelajaran hingga saat ini adalah aliran behaviouristic. Aliran behaviouristic ini menekankan pada terbentuknya perilaku yang tampak sebagai hasil belajar. Teori behaviouristic dengan model hubungan stimulus respon, mendudukkan orang yang belajar sebagai individu yang pasif. Respon atau perilaku tertentu dengan menggunakan metode drill atau pembiasaan semata. Munculnya perilaku akan semakin kuat bila diberikan reinforcement (penguatan) belajar dan akan menghilang bila dikenai hukuman (sanksi). Menurut teori behaviouristic, belajar adalah perubahan tingkah laku sebagai akibat dari adanya interkasi antara stimulus dan respon. Dengan kata lain, belajar merupakan bentuk perubahan yang dialami siswa dalam hal kemampuannya untuk bertingkah laku dengan cara yang baru sebagai hasil interkasi antara stimulus dan respon. Seseorang dianggap telah belajar sesuatu apabila ia dapat menunjukkan perubahan tingkah lakunya secara dinamis dan baik. Menurut teori ini yang terpenting adalah masukan atau input yang berupa stimulus dan keluaran atau output yang berupa respon. Menurut teori behaviouristic, apa yang terjadi di antara stimulus dan respon di
\end{abstract}

\footnotetext{
${ }^{1}$ Novi Irwan Nahar, "PENERAPAN TEORI BELAJAR BEHAVIORISTIK DALAM PROSES PEMBELAJARAN,” NUSANTARA : Jurnal Ilmu Pengetahuan Sosial 1, no. 1 (December 26, 2016), http://jurnal.um-tapsel.ac.id/index.php/nusantara/article/view/94.
} 
anggap tidak penting diperhatikan karena tidak dapat diamati dan tidak dapat diukur. Yang dapat diamati hanyalah stimulus dan respon oleh sebab itu, apa saja yang diberikan guru (stimulus) dan apa saja yang dihasilkan siswa (respon), semuanya harus dapat diamati dan dapat diukur. Teori ini mengutamakan pengukuran sebab pengukuran merupakan suatu hal yang penting untuk melihat terjadi tidaknya perubahan tingkah laku tersebut. ${ }^{2}$

Kata-kata kunci: pembelajaran, teori behaviouristic, psikologi belajar, mutu Pendidikan, belajar.

\section{PENDAHULUAN}

Teori belajar yang menekankan terhadap perubahan perilaku siswa adalah teori belajar behavioristik. Dilihat dari pengertiannya teori belajar behavioristik merupakan suatu teoripsikologi yang berfokus pada perilaku yang nyata dan tidak terkait dengan hubungan kesadaran atau kontruksi mental. Ciri utama teori belajar behavioristik adalah guru bersikap otoriter dan sebagai agen indukstrinasi dan propaganda dan sebagai pengendali masukan perilaku. Hal ini dikarenakan teori behavioristik menganggap manusia itu bersifat pasif dan segala sesuatunya tergantung pada stimulus yang didapatkan. Sasaran dituju dari pembelajaran ini adalah agar terjadi perbahan perilaku siswa kea rah yang lebih baik. Selaindalam pemberian poin terhadap pelanggaran aturan sekolah, teori belajar behavioristik juga diterapkan dalam pembelajaran.

Teori belajar merupakan gabungan prinsip yang yang saling berhubungan dan penjelasan atas sejumlah fakta serta penemuan yang berkaitan dengan peristiwa belajar. penggunaan teori belajar dengan langkah-langkah p[engembangan yang benar dan pilihan materi pembelajaran serta penggunaan unsur desain pesan yang baik dapat memberikan kemudahan kepada siswa dalam memahami sesuatu yang dipelajari. Selain itu, suasana belajar akan terasa lebih santai dan menyenangkan. Proses belajar pada hakikatnya adalah kegiatan mental yang tidak tampak. Artinya, proses perubahan yang terjadi dalam diri seseorang yang sedang belajar tidak dapat disaksikan dengan jelas tetapi dapat dilihat dari gejala-gejala perubahan perilaku. ${ }^{3}$

\section{KAJIAN TEORI}

Menurut teori Ivan P. Pavlov (1849 - 1936), ilmuwan rusia yang mengembangkan teori perilaku melalui percobaan tentang anjing dan air liurnya. Proses yang ditemukan oleh Ivan Pavlov, perangsang yang asli dan netral pada rangsangan biasanya secara berulangulang dipasangkan dengan unsur penguat yang menyebabkan suatu reaksi. Perangsang netral disebut perangsang bersyarat atau terkondisionir, yang disingkat dengan CS (Conditioned Stimulus). Rekasi alami atau reaksi yang tidak dipelajari disebut reaksi bersyarat atau CR (Conditioned Respond). Pavlov mengaplikasikan istilah-istilah itu sebagai suatu penguat.

\footnotetext{
${ }^{2}$ Victry Erlitha Picauly, "BELAJAR DAN PEMBELAJARAN BERDASARKAN TEORI PSIKOLOGI BELAJAR BEHAVIORISTIK,” JURNAL PENDIDIKAN ILMU SOSIAL 22, no. 1 (2013), https://doi.org/10.17509/jpis.v22i1.2200.

${ }^{3}$ Nahar, "PENERAPAN TEORI BELAJAR BEHAVIORISTIK DALAM PROSES PEMBELAJARAN."
} 
Maksudnya setiap agen seperti makanan, mengurangi sebagian dari suatu kebutuhan. Dengan demikian, dari mulut anjing akan keluar air liur sebagai reaksi terhadap makanan. Apabila suatu rangsangan netral, seperti sebuah bell atau genta dibunyikan bersamaan dengan waktu penyajian maka peristiwa itu akan memunculkan air liur.

Menurut Dahar dalam bukunya teori-teori Belajar menjelaskan dalam tahun-tahun terakhir dari abad ke 19 dan tahun-tahun permulaan abad ke-20, Pavlov dan kawan-kawan mempelajari proses pencernaan dalam anjing. Selama penelitian mereka para ahli ini memperhatikan perubahan dalam waktu dan kecepatan pengeluaran air liur. Dalam eksperimen-eksperimen ini Pavlov dan kawan-kawannya menunjukkan, bagaimana belajar dapat memengaruhi perilaku yang selama ini disangka refleksif dan tidak dapat dikendalikan, seperti pengeluaran air liur. Berangkat dari pengalamannya, Pavlov mencobamelakukan eksperimen dalam bidang psikologi dengan menggunakan anjing sebagi subjek penyelidikan.Adapun langkah-langkah eksperimen yang dilakukan Pavlovsebagai berikut:

Anjing dioperasi kelenjar ludahnya sedemikian rupa sehingga memungkinkan penyelidik dapat memeriksa dan mengukur dengan teliti air ludah yang keluar dari mulut anjing dengan pipa sebagai respons terhadap perangsang makanan (berupa serbuk daging) yang disodorkan ke mulutnya. Dengan demikian dapat disimpulkan bahwa anjing yang melihat makanan.

Ketika Anjing disodorkan makanan dan pada saat yang sama garputala dideringkan dan anjiang tetap mengeluarkan air liur karena sesudah itu dia mendapatkan makanan. Selanjutnya pada eksperimen berikutnya garputala dideringkan dan anjing mendengar maka air liur pun tetap keluar. Dengan demikian stimulus yang dikondisikan menyebabkan perubahan tingkah laku dari anjing.

Contoh video :

- https://youtu.be/asmXyJaXBC8

- Ulangan 6: 7 "Haruslah engkau mengajarkannya berulang-ulang kepada anakanakmu dan membicarakannya apabila engkau duduk di rumahmu, apabila engkau sedang dalam perjalanan, apabila engkau berbaring, dan apabila engkau bangun."

- Amsal 22: 6 "Didiklah orang muda menurut jalan yang patut baginya, maka pada masa tuanya ia tidak akan menyimpang dari pada jalan itu."

\section{METODE}

Metode yang digunakan untuk mengolah data kelompok adalah metode kualitatif deskriptif $^{4}$ Menerapkan metode neurosains pada peserta didik untuk mengubahkan karakter

\footnotetext{
${ }^{4}$ Hengki Wijaya and Helaluddin Helaluddin, Analisis Data Kualitatif Sebuah Tinjauan Teori \& Praktik (Makassar: Sekolah Tinggi Theologia Jaffray Makassar, 2019).
} 
peserta didik. ${ }^{5}$ Model pembelajaran yang dgunakan adalah pembelajaran kooperatif TPS. ${ }^{6}$ Metode pembelajaran 5P oleh Walker. ${ }^{7}$

\section{$\underline{\text { Contoh 1: }}$}

Dalam pelayanan anak sekolah minggu, seorang guru perlu menanamkan nilai kehidupan yang alkitabiah seperti kemurahan, saling mengasihi, dll. Nilai ini perlu menjadi perilaku / gaya hidup / karakter anak-anak sekolah minggu tersebut mulai sedini mungkin sehingga kelak ketika mereka dewasa, mereka hidup sesuai dengan nilai-nilai yang telah ditanamkan tersebut di atas.

Guru tersebut perlu mengajarkannya nilai-nilai tersebut secara sungguh-sungguh dan berulang-ulang sehingga itu menjadi karakter mereka dan menjadi prinsip hidup mereka.

Hasil dari nilai-nilai yang ditanamkan dan diajarkan secara berulang-ulang tersebut akan memperlihatkan perubahan yang nyata terhadap perilaku anak-anak tersebut.

Anak-anak tersebut lebih mementingkan nilai-nilai alkitabiah dalam menjalani kehidupan melebihi kebutuhan material yang ditawarkan oleh dunia.

\section{Contoh 2:}

Teori pavlov dalam penerapannya (Stimulus - Respons)

Misalnya seseorang yang malas belajar atau malas membaca bisa diberi rangsangan atau stimulus agar perilakunya bisa berubah menjadi seseorang yang rajin belajar atau membaca, biasanya orang akan lebih semangat dan senang membaca sambil makan atau sambil dengar musik. Dengan demikian kita dapat melakukannya kepada orang yang malas belajar yaitu dengan menyiapkan makanan sehingga secara perlahan ia akan senang membaca buku sampai kepada perubahan perilakunya yaitu walaupun tanpa menyediakan makanan ia akan senang membaca karena sudah terbiasa.

Contoh videos:

\section{- https://youtu.be/JoJVHmKNGvY}

\section{HASIL DAN PEMBELAJARAN}

Hasil dan pembelajaran di kelas bersama mahasiswa lain pada tanggal 12 Desember 2019, memperlihatkan ada beberapa mahasiswa yang berpartisipasi memberikan pengalamannya dalam menghasilkan suatu hasil yang positif dan memberikan stimulus

\footnotetext{
${ }^{5}$ Hengki Wijaya, "Pendidikan Neurosains Dan Implikasinya Dalam Pendidikan Masa Kini," 2018, https://repository.sttjaffray.ac.id/media/269017-pendidikan-neurosains-dan-implikasinya-d-5854b17f.pdf.

${ }^{6}$ Kule Kule and Hengki Wijaya, "Penerapan Model Pembelajaran Cooperative Learning Tipe Think Pair Share Pada Materi Listrik Dinamis Untuk Meningkatkan Hasil Belajar Siswa Kelas XI TKR1 SMK Negeri 2 Tarakan," Jurnal Ilmu Pendidikan Fisika (JIPF) 3, no. 2 (2018): 47-51.

${ }^{7}$ Roland Walker, "Learning That LASTS," n.d., https://wycliffe.fi/wpcontent/uploads/2018/12/intro-to-learning-that-lasts-walker.pdf.
} 
untuk sebagai motivasi atau penyemangat dalam menghasilkan kebiasaan yang mendukung tercapainya hasil/tujuan.

Pengalaman masa kecil yang baik diingat dan dilakukan secara terus-menerus hingga dewasa. Stimulus yang diberikan orangtua memberikan pengaruh positif untuk perubahan perilaku di masa yang akan dating. Perilaku yang buruk dengan sendirinya diubahkan menjadi perilaku yang benar di hadapan Tuhan (Ef. 4:17-32). ${ }^{8}$ Hal yang baik yang dialami akan terus-menerus dilakukan dan menjadi habitus. Bila diimplikasikan dalam kepemimpinan organisasi maka kepemimpinan Yesus dan Para Rasul adalah kepemimpinan yang mengandalkan Tuhan Yesus dimana pada masa yang lalu mereka menggunakan hikmat manusia untuk memimpin tetapi setelah mengenal Allah yang benar maka mereka memimpin seperti teladan Yesus. ${ }^{9}$

Demikian halnya anak-anak zaman milenial ini siapakah yang mereka andalkan, dan siapakah yang mereka sembah? Apakah teknologi telah menggantikan Allah atau menggunakan teknologi sebagai pendukung kelancaran dalam menyembah Allah yang Esa. Tentunya motivasi kita dalam menyembah Tuhan adalah yang terpenting, bukan karena gereja telah menyediakan "daging" yang kita pahami sebagai makanan rohani, tetapi lebih terpenting arti menyembah Allah adalah kita menjadi sati dengan Allah dalah ibadah. ${ }^{10} 11$

\section{Daftar Pustaka}

Ipaq, Eli Wilson, and Hengki Wijaya. "Kepemimpinan Para Rasul Dan Relevansinya Bagi Pemimpin Gereja Di Era Revolusi Industri 4.0.” Integritas: Jurnal Teologi 1, no. 2 (2019): 112-22.

Kule, Kule, and Hengki Wijaya. "Penerapan Model Pembelajaran Cooperative Learning Tipe Think Pair Share Pada Materi Listrik Dinamis Untuk Meningkatkan Hasil Belajar Siswa Kelas XI TKR1 SMK Negeri 2 Tarakan.” Jurnal Ilmu Pendidikan Fisika (JIPF) 3, no. 2 (2018): 47-51.

Nahar, Novi Irwan. "PENERAPAN TEORI BELAJAR BEHAVIORISTIK DALAM PROSES PEMBELAJARAN.” NUSANTARA : Jurnal Ilmu Pengetahuan Sosial 1, no. 1 (December 26, 2016). http://jurnal.umtapsel.ac.id/index.php/nusantara/article/view/94.

Picauly, Victry Erlitha. "BELAJAR DAN PEMBELAJARAN BERDASARKAN TEORI PSIKOLOGI BELAJAR BEHAVIORISTIK." JURNAL PENDIDIKAN ILMU SOSIAL 22, no. 1 (2013). https://doi.org/10.17509/jpis.v22i1.2200.

Tison, Tison, and Jermia Djadi. "Pengajaran Tentang Ibadah Berdasarkan Surat Ibrani 10:19-25 Dan Implimentasinya Dalam Kehidupan Orang Percaya Pada Masa Kini.” Jurnal Jaffray 11, no. 1 (April 2, 2013): 37-66. https://doi.org/10.25278/jj71.v11i1.67.

\footnotetext{
${ }^{8}$ Hengki Wijaya, "Pengenaan Manusia Baru Di Dalam Kristus: Natur, Proses, Dan Fakta Serta Implikasi Teologis Dan Praktisnya,” Jurnal Jaffray 14, no. 1 (March 22, 2016): 109, https://doi.org/10.25278/jj71.v14i1.194.

${ }^{9}$ Eli Wilson Ipaq and Hengki Wijaya, "Kepemimpinan Para Rasul Dan Relevansinya Bagi Pemimpin Gereja Di Era Revolusi Industri 4.0," Integritas: Jurnal Teologi 1, no. 2 (2019): 112-22.

${ }^{10}$ Hengki Wijaya, "Ulasan Buku: Whatever Happened To Worship A Call To True Worship," Jurnal Jaffray 15, no. 1 (March 19, 2017): 148, https://doi.org/10.25278/jj71.v15i1.241.

${ }^{11}$ Tison Tison and Jermia Djadi, "Pengajaran Tentang Ibadah Berdasarkan Surat Ibrani 10:19-25 Dan Implimentasinya Dalam Kehidupan Orang Percaya Pada Masa Kini," Jurnal Jaffray 11, no. 1 (April 2, 2013): 37-66, https://doi.org/10.25278/jj71.v11i1.67.
} 
Walker, Roland. "Learning That LASTS," n.d. https://wycliffe.fi/wpcontent/uploads/2018/12/intro-to-learning-that-lasts-walker.pdf.

Wijaya, Hengki. "Pendidikan Neurosains Dan Implikasinya Dalam Pendidikan Masa Kini," 2018. https://repository.sttjaffray.ac.id/media/269017-pendidikanneurosains-dan-implikasinya-d-5854b17f.pdf. "Pengenaan Manusia Baru Di Dalam Kristus: Natur, Proses, Dan Fakta Serta Implikasi Teologis Dan Praktisnya." Jurnal Jaffray 14, no. 1 (March 22, 2016): 109. https://doi.org/10.25278/jj71.v14i1.194.

"Ulasan Buku: Whatever Happened To Worship A Call To True Worship." Jurnal Jaffray 15, no. 1 (March 19, 2017): 148. https://doi.org/10.25278/jj71.v15i1.241.

Wijaya, Hengki, and Helaluddin Helaluddin. Analisis Data Kualitatif Sebuah Tinjauan Teori \& Praktik. Makassar: Sekolah Tinggi Theologia Jaffray Makassar, 2019. 